\title{
Geographical Assessment of the Impact of MGNREGS Created Common Property Resources on Gender: A Ground Based Discussion
}

\author{
Sarmistha Saha
}

Department of Geography, Michael Madhusudan Memorial College, Durgapur, West Bengal, India

Corresponding author: sarmis2008mailbox@gmail.com

\begin{abstract}
MGNREGS is a much discussed rural development scheme currently operational in all rural districts of India. It's vast extension and decentralized nature of planning has made it special to Indian economy. Employment related aspects of this scheme has always remain the focus of discussion since its inception. However, little attempts have been made to relate MGNREGS created CPRs and gender. This paper provides an empirical research on the impact of MGNREGS generated CPRs on gender. The impact is assessed through a structured questionnaire and the identification of mostly used CPRs across gender. The degree of ease of livelihood and the utilization pattern of these CPRs are different across gender in study area. In the last section, this paper provides suggestions regarding the improvement of the gendered access of CPRs and its sustainable use.
\end{abstract}

Keywords: MGNREGS, CPR, Livelihood, Sustainable Use, CPR Management

The concept of livelihoods gradually gained a significant importance to the issues of poverty reduction and human development. Livelihoods may be defined as means by which households obtain and maintain access to the resources necessary to ensure their immediate and long term survival (Scoones, 1998). A livelihood comprises the capabilities, assets (stores, resources, claims, and access) and activities required for a means of living; a livelihood is sustainable which can cope with and recover from stress and shocks, maintain or enhance its capabilities and assets, and provide sustainable livelihood opportunities for the next generation (Chambers and Conway, 1992). Article 39A of the Directive Principles of the Indian Constitution, enjoins the State to ensure that every citizen has adequate means of livelihood. UNDP (2003) also consider livelihoods as an important factor responsible for eradicating extreme hunger and poverty and thereby attaining a better human development index.

"The studies have documented that MGNREGS activities, apart from providing income and employment, provided multiple environmental services, such as increased ground water recharge, increased ground water percolation, enhanced water storage in tanks, increase soil fertility, reclamation of degraded lands, and carbon sequestration" (Raveendranath et al. 2009).

\section{Methodology \& Data Source}

To study the gendered impact of MGNREGS generated resources, a primary study has been done in silampur village of Kanksa mouza in West Bengal as a part of the UGC sponsored minor project "Gender Specific Utilization of Common Property Resources: A Micro Level Study of MGNREGS Generated CPRs Utilization in Rural Part of Burdwan, West Bengal" 2015 with 201 number of respondents. The methodology involves simple random sampling on the basis of structured questionnaire, pilot survey, final survey and focussed group discussions. 
Data source of the study refers to primary research based on a set of structured questionnaire.

\section{An analysis of the Situation}

Table 1: Profile of the Sample Respondents

\begin{tabular}{|c|c|c|c|c|c|}
\hline & \multicolumn{4}{|c|}{$\begin{array}{c}\text { Whether Using MNREGS } \\
\text { Generated CPRs }\end{array}$} & \multirow[t]{3}{*}{$\begin{array}{l}\text { Total } \\
\mathrm{N} \%\end{array}$} \\
\hline & \multirow{2}{*}{\multicolumn{2}{|c|}{$\begin{array}{l}\text { YES } \\
\mathrm{N} \%\end{array}$}} & \multirow{2}{*}{$\begin{array}{l}\text { NO } \\
\text { N \% }\end{array}$} & \multirow{2}{*}{$\begin{array}{c}\text { No Ans } \\
\text { N\% }\end{array}$} & \\
\hline & & & & & \\
\hline Gender & Male & 8391.20 & 88.80 & 00.0 & 91100 \\
\hline $\begin{array}{l}\text { Profile of the } \\
\text { Respondents }\end{array}$ & Female & 9586.36 & 1412.72 & 10.92 & 110100 \\
\hline Total & 178 & 88.56 & 2210.99 & 10.45 & 201100 \\
\hline
\end{tabular}

Source: Field survey, September 2015-December 2016.

Out of 201 total respondents, number of male respondents reported using MGNREGS created CPRs are 83 , i.e. $91.20 \%$ of total male respondents (91). For female, the representation is slightly less, 95 out of total 110 female respondents. (86.36\%). In general, $88.56 \%$ respondents of the total are using these common property resources in the study area. MGNREGS has created (a) ponds (b) roads (c) plantation ground (d) drain (e) earthen embankment (f) levelled land etc. in the sample village. The survey was conducted in two parts; one on the basis of the structured questionnaire and recording of the responses and another is FGD with selected few of men and women. (Those who are using at least three assets daily in a day). Though it is extremely complicated to assess the impact of the resources due to utilization overlap, it is simplified as the recording of major use (three per respondent) as per the time duration and intensity of the use. The major three resources used in the study area are ponds, embankment and roads created by MGNREGS. Following table represents the category of recorded responses.

Table 2: Impact of MGNREGS on Village Livelihood

\begin{tabular}{|c|c|c|c|}
\hline & \multicolumn{2}{|c|}{$\begin{array}{l}\text { Whether Assets Built } \\
\text { by MGNREGS has } \\
\text { Resulted the Ease of } \\
\text { Livelihood }\end{array}$} & \multirow[t]{3}{*}{$\begin{array}{l}\text { Share out of } \\
\text { Total no. of } \\
\text { Respondents } \\
\quad \text { N\% }\end{array}$} \\
\hline & YES & NO & \\
\hline & $\mathbf{N} \%$ & $\mathbf{N} \%$ & \\
\hline Sex of the & $74(81.31 \%)$ & $17(18.69 \%)$ & $91(45.27 \%)$ \\
\hline Respondent Female & $88(80.00 \%)$ & $22(20.00 \%)$ & $110(54.73 \%)$ \\
\hline Total & $162(80.59 \%)$ & $39(19.41 \%)$ & $201(100 \%)$ \\
\hline
\end{tabular}

Source: Filed survey, September 2015-December 2016.
Out of the 178 users of MGNREGS created CPRs, 162 had given the positive response regarding their ease of livelihood (91.01\%) due to MGNREGS implementation. Those who reported no change in their livelihood are from three categories, (a) those who are using MGNREGS created CPRs but not satisfied with it $(\mathrm{N}=16),(\mathrm{b})$ those who are not using MGNREGS created assets at all $(\mathrm{N}=38)$ and (c) those who did not give any definite answer regarding the ease of livelihood and MGNREGS generated CPRs $(\mathrm{N}=1)$.

Table 3: Benefits Achieved from Earthen Embankment in Study Area

\begin{tabular}{lcccc}
\hline $\begin{array}{l}\text { Benefits Achieved } \\
\text { from Embankment }\end{array}$ & $\begin{array}{c}\text { Total } \\
\text { Male }\end{array}$ & $\begin{array}{c}\text { Total } \\
\text { Female }\end{array}$ & $\begin{array}{c}\text { \%age of } \\
\text { Male }\end{array}$ & $\begin{array}{c}\text { \%age of } \\
\text { Female }\end{array}$ \\
\hline $\begin{array}{l}\text { Reduction of Trauma } \\
\text { For Flood }\end{array}$ & 53 & 56 & 71.62 & 63.64 \\
$\begin{array}{l}\text { Improved Connectivity } \\
\text { To Schools, Market \& }\end{array}$ & 1 & 12 & 1.35 & 13.64 \\
$\begin{array}{l}\text { Religious Places } \\
\text { More Recreation }\end{array}$ & 11 & 1 & 14.87 & 1.14 \\
$\begin{array}{l}\text { Ease of Water } \\
\text { Collection For }\end{array}$ & 0 & 0 & 0.0 & 0.0 \\
$\begin{array}{l}\text { Drinking } \\
\text { Ease of Religious }\end{array}$ & 0 & 3 & 0.0 & 3.40 \\
$\begin{array}{l}\text { Practices } \\
\text { Ease of Using/ }\end{array}$ & 0 & 0 & 0.0 & 0.0 \\
$\begin{array}{l}\text { Accessing Toilets } \\
\text { Help in Cultivation }\end{array}$ & 9 & 16 & 12.16 & 18.18 \\
Others & 0 & 0 & 0.0 & 0.0 \\
\hline Total & $\mathbf{7 4}$ & $\mathbf{8 8}$ & $\mathbf{1 0 0}$ & $\mathbf{1 0 0}$ \\
\hline
\end{tabular}

Source: Field survey, September 2015-December 2016.

Table 3 depicts the highest percentage of respondents in both category are benefitted from the earthen embankment created under MGNREGS in the study area .This has resulted the vulnerability reduction to a great extent. Basanti Devi (54) has reported, "We live so close to river that it was our fate to struggle with flood in almost every year. For me, this was the most hectic and tiring period of my life as I had to cook within and to look after my children who often fall sick in that season. After creation of that embankment, we are saved from hectic schedule of monsoon days, saved from going to temporary shelter and to arrange for livelihood in a mess for almost one month". Though the embankment is not fully capable of restricting flood in optimum level, but it has got the recognition of best CPR in the village created through MGNREGS for saving 
human lives together with livestock. It has helped to drastically reduce the domestic hazard of the village women in monsoon season in last five years. For women, the second benefit is the help in cultivation due to constant supply of water. This place is used by village male as a place to roam around and community gathering in the evening. Females, on the other hand are have not reported positively for social restrictions.

Table 4: Benefits Achieved from Newly Generated/ Regenerated Ponds in The Study Area

\begin{tabular}{|c|c|c|c|c|c|}
\hline $\begin{array}{l}\text { Purpose of } \\
\text { Utilization of } \\
\text { ponds }\end{array}$ & $\begin{array}{l}\text { Total } \\
\text { Male }\end{array}$ & $\begin{array}{c}\text { Total } \\
\text { Female }\end{array}$ & $\begin{array}{c}\text { \%age of } \\
\text { Male }\end{array}$ & $\begin{array}{l}\% \text { oage of } \\
\text { Female }\end{array}$ & $\begin{array}{l}\text { Average } \\
\text { \%age of } \\
\text { Male \& } \\
\text { Female }\end{array}$ \\
\hline Flood Control & 2 & 5 & 2.70 & 5.68 & 4.19 \\
\hline $\begin{array}{l}\text { Recreational } \\
\text { Purpose }\end{array}$ & 23 & 3 & 31.08 & 3.41 & 17.25 \\
\hline Bathing Purpose & 24 & 27 & 32.43 & 30.68 & 31.56 \\
\hline $\begin{array}{l}\text { Purpose of } \\
\text { Washing Cloths } \\
\text { \& Utensils }\end{array}$ & 1 & 21 & 1.35 & 23.86 & 12.61 \\
\hline $\begin{array}{l}\text { Purpose of } \\
\text { Religious } \\
\text { Practices }\end{array}$ & 4 & 2 & 5.41 & 2.27 & 3.84 \\
\hline $\begin{array}{l}\text { Purpose of } \\
\text { Using/Accessing } \\
\text { Toilets }\end{array}$ & 3 & 2 & 4.05 & 2.27 & 3.16 \\
\hline $\begin{array}{l}\text { Purpose of } \\
\text { Cultivation }\end{array}$ & 15 & 18 & 20.27 & 20.45 & 20.36 \\
\hline $\begin{array}{l}\text { Not Reported } \\
\text { Any Benefit }\end{array}$ & 2 & 10 & 2.70 & 11.36 & 7.03 \\
\hline Total & 74 & 88 & 100.00 & 100.00 & ........... \\
\hline
\end{tabular}

Source: Filed Survey, September 2015-December 2016.

Pond is the third significant CPR preferred across gender in the study area. It has been observed that the ponds created by MGNREGS are having great impact in the domestic life of village women. $74 \%$ of women FGD respondents agreed with the fact that these newly created /renovated ponds are playing good role in helping their domestic life. They are now enabled to collect water from the newly created ponds for their domestic use, like bathing of cattle, fetching water to kitchen garden, bath of their own and other domestic uses. Though none of these ponds are that deep which can provide drinking water and supply water throughout the summer, but major part of the year is served by these ponds. Ponds are turned to be most beneficial CPR for village women. These are saving time and hardship of water collection, as most of the households in observed village is having no personal water source like well and tube well.

Another significant observation regarding MGNREGS created ponds is preference of pond is more or less similar across gender in the study area. For male, ponds are the place to fetch water for cultivation, bath, bathing of cattle and sometimes, a place to roam around. For female, this is the most significant source of fetching water for self and domestic use, kitchen gardening and for religious practices (like suryapranam).

Table 5: Benefits Achieved from Newly Generated/ Regenerated Roads in The Study Area

\begin{tabular}{|c|c|c|c|c|c|}
\hline $\begin{array}{l}\text { Purpose of } \\
\text { Utilization of } \\
\text { roads }\end{array}$ & $\begin{array}{l}\text { Total } \\
\text { Male }\end{array}$ & $\begin{array}{c}\text { Total } \\
\text { Female }\end{array}$ & $\begin{array}{c}\% \text { age } \\
\text { of } \\
\text { Male }\end{array}$ & $\begin{array}{c}\text { \%age } \\
\text { of } \\
\text { Female }\end{array}$ & $\begin{array}{c}\text { \%age of } \\
\text { Male \& } \\
\text { Female to } \\
\text { total N }\end{array}$ \\
\hline $\begin{array}{l}\text { Ease of access to } \\
\text { collect drinking } \\
\text { water }\end{array}$ & 1 & 35 & 1.35 & 39.77 & 3622.22 \\
\hline $\begin{array}{l}\text { Bathing Purpose } \\
\text { (human \& } \\
\text { livestock) }\end{array}$ & 17 & 14 & 22.97 & 15.91 & 3119.13 \\
\hline $\begin{array}{l}\text { Ease of access to } \\
\text { daily market }\end{array}$ & 25 & 13 & 33.78 & 14.78 & 3823.46 \\
\hline $\begin{array}{l}\text { Ease of access } \\
\text { to at the time of } \\
\text { flood }\end{array}$ & 8 & 11 & 10.82 & 12.5 & 1911.73 \\
\hline $\begin{array}{l}\text { Ease of access } \\
\text { to educational } \\
\text { centres }\end{array}$ & 5 & 10 & 6.76 & 11.36 & 159.26 \\
\hline $\begin{array}{l}\text { Ease of access } \\
\text { to recreational } \\
\text { centres }\end{array}$ & 13 & 2 & 17.56 & 2.27 & 159.26 \\
\hline $\begin{array}{l}\text { Not Reported } \\
\text { Any Benefit }\end{array}$ & 5 & 3 & 6.76 & 3.41 & 84.94 \\
\hline Total & 74 & 88 & 100.00 & 100.00 & 162100.00 \\
\hline
\end{tabular}

Source: Field survey, September 2015-December 2016.

Highest percentage of female $(39.77 \%)$ respondents have reported ease of access to collect drinking water due to newly created village roads. The highest percentage of male $(33.78 \%)$ is seen I the category of ease of access to daily market. While men are seeing village roads as a medium to quick access to workplace and field, female of the village are mostly preferring this asset for helping them to collect water from the pond, fuelwood from 
the nearby places and safely sending their child to school. Village roads built through MGNREGS in the study area are connecting all parts of the village as well as outward high road. These are significant for better connectivity to market, schools and places for social activities like temples, Idgah etc. Folowing table reveals the reason for the choice of first preference across gender.

Following are the livelihood changes, as reported by the village men and women in FGDs:

1. Newly created/regenerated ponds in the village helped in daily livelihood by reducing the time for water collection. This is especially helpful for village women as water collection is seemed to be assigned as women related work in rural India. This benefit is exclusively achieved by rural women across all age groups in the study area.

2. The availability of water has increased a lot than previous years. This available water is utilized in bath, domestic purposes and in some cases, for kitchen gardening and cultivation in few cases. The increased availability has helped the villagers of the study area irrespective of gender.

3. Ponds are helpful for maintaining kitchen garden in some cases therefore ensuring some more vegetables in daily meal as compared to others.

4. Availability of water for bathing is more after the implementation of MGNREGS. Earlier, the villagers have faced water crisis before the introduction of pipeline in scorching summer. The MGNREGS created ponds are helpful as an additional source of secured availability, beside pipeline supply.

5. Ease of access to all parts of village and village with main road is accelerated compared to previous years. FGD with women revealed that this ease of access has enhanced the participation of girl child in school and marketing of the home made products like the vegetables of the kitchen garden, cow dung cakes, embroidery works, poultry and dairy products by women only and thus helped in the rise of income and their own savings.

6. Levelled land is now used as playground, mostly for boys. These are avoided by girls because of the social restrictions.

7. Earthen embankment has significantly contributed to the reduction of flood vulnerability, therefore increased the livelihood opportunities for both men and women.

8. Embankment is highly successful in mitigating the temporary migration to shelter at rainy season and therefore the livelihood opportunities enhanced. This has reduced the livelihood vulnerability of village women to a great extent.

9. Embankment is helping the village males not to be water -trapped in rainy season and therefore temporary migration of males is possible in rainy season as agricultural labourer to the nearby agro-rich districts. Therefore, it helped the livelihood by paving the way of earning.

\section{Suggestions for the improvement of the situation}

Observing the ground situation of MGNREGS created resources, following are the suggestions for the improvement of the situation:

1. CPRs should be created keeping in view the long term achievement of the village rather than mere employment days generation. These should be of good quality and for the maximum benefits of villagers.

2. CPRs helping more to village women should be given more concern and pre-work survey is needed to address the need of the village women.

3. A regular awareness campaign is needed to make the people specially women aware about the CPR generation part of the scheme and its usefulness.

4. Awareness level must be raised regarding conservation of resources and schools should incorporate some conservation aspects within young minds.

5. More participation of women is needed in village meetings to ensure the most needed CPR in the village for the benefit of women and girls. 
6. Village authority should ensure good quality CPRs and a regular inspection and village audit is needed to monitor the same.

\section{CONCLUSION}

On a conclusive note, it can be said that the safety net programmes like MGNREGS should include women's voices and interests keeping in view the social relations, family structure and existing cultural norms. These programmes should seek to enhance women's access to the newly created resources as well. Creation of explicit awareness about women's access to CPRs will enhance their control on it and hence will ensure the long term preservation as women has naturally got the preservation attitude towards nature much more than men. Recognizing women's participation constraints and their role in manging CPRs may result the best benefit out of it. According to World Bank report, "programmes that affect access to and management of common property, such as natural resource management programme, should recognize women's dependence on these resources and accommodate gender differentiated management practices". It is concluded from the field survey that the awareness and empowerment of villagers across gender will reduce the vulnerabilities of their own to a great extent together with the enhancement of livelihood opportunities. This will again boost up the women's access to the CPRs. A broader understanding of gender dimensions of CPR management will help the policy makers to formulate a more effective policy for sustainable development.

\section{REFERENCES}

Chambers, R. and Conway, R. 1992. Sustainable rural livelihoods: Practical concepts for the $21^{\text {st }}$ century. IDS discussion paper. 296: p.127-130.

Ravindranath,N.H, Parama, V.R. et al. 2009. Environmental Services, Vulnerability Reduction and Natural Resource conservation from NREGA Activities - Case Study of Chitradurga District Indian Institute of Science, Centre for Sustainable Technologies, Bengaluru.

Scoones, I. 1998. Sustainable Rural Livelihoods: A. Framework for Analysis. IDS Working Paper 72.

UNDP. 2003, Gender and disaster", available at http:// www.undp.org/content/dam/undp/library/crisis $\% 20$ prevention/disaster/7Disaster\%2 0Risk\%20Reduction \%20 -\%20Gender.pdf accessed on 6th April, 2016.

WorldBank,2009. Gender and agriculture sourcebook", available at https://books.google.co.in/books?id=XxBrq6hTs_ UC\&pg=PA140\&lpg=PA140\&dq, accessed on 6th May, 2016.

World Bank, 2016. Module 10, “Gender and natural resources management", available at. http://siteresources. worldbank.org/INTGENAGRLIVSOUBOOK/Resources/ Module10.pdf accessed on $4^{\text {th }}$ April. 
